\title{
Economic Impact of the 2005 Red Tide Event on Commercial Shellfish Fisheries in New England
}

\author{
Di Jin $^{\mathrm{a}^{*}}$, Eric Thunberg ${ }^{\mathrm{b}}$, Porter Hoagland ${ }^{\mathrm{a}}$ \\ ${ }^{\mathrm{a}}$ Marine Policy Center \\ Woods Hole Oceanographic Institution \\ Woods Hole, Massachusetts 02543 \\ ${ }^{\mathrm{b}}$ Social Sciences Branch \\ Northeast Fisheries Science Center \\ National Marine Fisheries Service \\ Woods Hole, Massachusetts 02543
}

October 4, 2007

*Corresponding author. Tel.:+1-508-289-2874; fax: +1-508-457-2184.

E-mail address: djin@whoi.edu (D. Jin).

Acknowledgements: This research was supported by the National Atmospheric and Oceanic Administration (NOAA) through the WHOI/NOAA Cooperative Institute on Climate and Ocean Research (CICOR) under award number NA17RJ1223. 


\title{
Economic Impact of the 2005 Red Tide Event on Commercial Shellfish Fisheries in New England
}

\begin{abstract}
Over the last several decades, harmful algal bloom (HAB) events have been observed in more locations than ever before throughout the United States. The 2005 bloom of Alexandrium fundyense was the most widespread and intense in New England waters since a similar event more than three decades ago. In this study, using historical data from the National Marine Fisheries Service, the Massachusetts Division of Marine Fisheries, and other sources, we develop estimates of the direct economic impacts of the 2005 event on commercial shellfish fisheries in Maine and Massachusetts. Results of our regression analyses suggest that the 2005 event had broad spatial and temporal effects on the shellfish market. In response to a supply shortage resulting from local closures, there was an increase in shellfish imports to New England during the red tide. Further, shellfish closures in Maine were the most likely cause of observable price changes on the Fulton Fish Market in New York.
\end{abstract}




\section{Introduction}

The 2005 bloom of Alexandrium fundyense was the most widespread and intense since a hurricane in 1972 spread the toxic dinoflagellate throughout southern New England waters. Shellfish beds in Massachusetts, Maine, and New Hampshire, as well as 15,000 square miles of federal waters, were closed for more than a month at the peak of the seafood harvesting season. The Massachusetts Division of Marine Fisheries estimated that the total economic impact associated with lost shellfish landings due to the bloom was close to $\$ 50$ million in the state alone. ${ }^{1}$ The US National Oceanic and Atmospheric Administration (NOAA) declared the event a "commercial fisheries failure,” and, for the first time in the region, the governors of Maine and Massachusetts officially declared red tide to be a disaster, clearing the way for fishermen to receive federal emergency assistance.

During the last several decades, harmful algal bloom (HAB) events have been observed in more locations than ever before throughout the United States. Virtually all coastal regions of the United States are now regarded as potentially subject to a wide variety and increased frequency of HABs (Hoagland et al. 2002). From a management perspective, it is crucial to begin developing an understanding of the scale of the economic costs to society of HAB events. The scale of economic losses can tell us something about the appropriate scale of actions to be taken to prevent or mitigate the losses. At the very least, if one can take some action that removes the threat of a harmful bloom, then no more resources (measured in financial terms) should be spent taking action than the actual economic losses associated with the bloom itself (Hoagland and Scatasta 2006).

\footnotetext{
${ }^{1}$ This estimate is a preliminary one developed by Hickey and Whittaker (2006); it includes both direct impacts (i.e., harvest losses) and indirect impacts (i.e., multiplier effects).
} 
Research on the economic impacts of red tide events is meager. Generally, existing impact assessments of $\mathrm{HAB}$ events often are rough estimates based on either limited observation or hypothetical events. Hoagland et al. (2002) compiled and reviewed disparate estimates of the economic effects of HABs for events in the United States during 1987-1992. Their study covered HAB effects of four basic types: public health, commercial fisheries, recreation and tourism, and monitoring and management. To examine the broader market effects of HABs, Wessells et al. (1995) developed a case study of the impacts of a toxic algae bloom contamination event in Prince Edward Island on demand for unaffected shellfish in Montreal. The study showed that there was a reduction in demand for unaffected shellfish following algae contamination due to negative press coverage and resulting consumer perception of product quality.

Along the Maryland coast of Chesapeake Bay, a 1997 bloom of Pfiesteria piscicida resulted in fish kills, primarily of menhaden (Brevoortia tyrannus). Upon learning of the bloom, the Maryland governor expressed concerns about the potential impact on public health, and he reacted by prohibiting commercial and recreational fishing in a number of Chesapeake tributaries. These prohibitions resulted in lost sales to seafood producers in most seafood categories, including those clearly unrelated to the bloom. A study of the economic impacts from this HAB event (Whitehead et al. 2003) concluded that a public announcement of a fish kill can lead to contractions in the demand for seafood. In the month following the Pfiesteria bloom, the authors estimated consumer surplus losses resulting from concerns about seafood safety at between $\$ 37$ and $\$ 72$ million in the mid-Atlantic region. An important further conclusion of this study was that public pronouncements assuring the safety of seafood may do little to reduce 
economic losses. Mandatory programs of seafood inspection appear to be more effective in protecting the public health and minimizing general consumer concerns about seafood quality.

The objectives of our study are twofold: (1) we aim to develop estimates of direct economic impacts of the 2005 event on commercial shellfish fisheries in Maine and Massachusetts using methods that are consistent with economic theory ${ }^{2}$; and (2) we aim to identify broader effects of the event on market supply channels and prices using empirical data from the shellfish industry. Oceanographers have indicated that another significant Alexandrium fundyense event will occur in the future due to the deposition of large quantities of algal cysts in New England ocean sediments (Anderson et al. 2005). If this is true, then the results of our study should provide useful information for policy- and decision-makers and the public in managing these events and in obtaining a more accurate assessment of the economic impacts of HABs.

The remainder of this paper is organized as follows. Section 2 presents background information on the 2005 red tide event. Section 3 describes the methods for calculating lost shellfish landings and for identifying and testing key market links. Data sources and the results of impact calculations and model estimations are summarized in

Section 4. Section 5 presents our conclusions.

\section{Background}

Alexandrium fundyense is a dinoflagellate that produces a toxin that may be concentrated in the tissues of shellfish as they filter seawater for food. The toxin may

\footnotetext{
${ }^{2}$ We focus on direct impacts (i.e., harvest losses), as they comprise an essential component for different types of economic analyses. For example, direct impacts may be used as data to specify a regional inputoutput model to estimate total economic impacts (the sum of direct, indirect, and induced impacts). We do not examine economic losses in other economic sectors such as recreational shellfishing, although these losses may be significant (Damery and Allen 2004).
} 
cause paralytic shellfish poisoning (PSP) in humans that eat the shellfish. Current management measures include toxicity testing of shellfish throughout the coastal region, and closures of shellfish beds when a toxicity threshold ${ }^{3}$ is exceeded (Vakalopoulos et al. 2006).

Alexandrium has historically bloomed in the Bay of Fundy, but blooms were not known to occur in the southwestern Gulf of Maine, including Massachusetts Bay, until 1972 when a slow-moving hurricane brought cells down the coast, presumably from the Bay of Fundy. Following the 1972 bloom, recurrent annual outbreaks have been observed in northern Massachusetts, New Hampshire, and western Maine. Further south, in Massachusetts Bay, shellfish toxicity was frequently observed from 1972-1993 but nearly absent from 1994-2004 (Anderson et al. 2005; Vakalopoulos et al. 2006).

The extensive bloom in 2005 was a result of favorable offshore circulation, wind, and river runoff, including two or more "northeaster" storms that pushed waters onshore. In addition, cysts were abundant in offshore sediments (Vakalopoulos et al. 2006). In 2005, record levels of PSP toxicity were measured at some locations where PSP had been known to occur, while at other locations PSP toxicity was measured for the first time ever. Record-level concentrations of algal cells were observed in the southwestern Gulf of Maine. Other records include the earliest toxicity, the longest closures, and the largest area affected (i.e., a large closure of federal waters). Disaster declarations were issued in Maine and Massachusetts, as shellfishermen were unable to harvest for prolonged periods over the affected areas. Figure 1 shows the progression of shellfish closures along the

\footnotetext{
${ }^{3}$ This level protects humans from illness or death.
} 
New England coast. Although most significant closures occurred from May to July, red tide related closures also were instituted in April and August. ${ }^{4}$

Direct economic losses to shellfish harvesters result from the coincidence of timing between environmental conditions ripe for a $\mathrm{HAB}$ and market demand (which typically peaks during the spring and summer tourist season). Even though PSP does not kill shellfish, the primary product form is a live product sold in a market with a distinct seasonal demand. This means that sales losses due to a PSP event in the spring or summer cannot be offset by increasing harvest later in the year because of much lower demand for live shellfish. In separate initial assessments in June 2005, Maine and Massachusetts projected that direct economic impacts on shellfish fisheries due to redtide closures were $\$ 560,000$ and $\$ 600,000$ per week, respectively. ${ }^{5}$ In another preliminary estimate, Hickey and Whittaker (2006) reported a total economic impact of \$46.17 million in the Massachusetts economy, which included direct impacts (i.e., harvest losses) of \$10.26 million and indirect impacts (i.e., multiplier effects) of \$35.91 million in seafood-related industries. These studies were developed in a somewhat ad hoc manner and did not account for potential market adjustments that would have affected estimates of impacts particularly on wholesale and retail market supplies.

\footnotetext{
${ }^{4}$ Massachusetts Division of Marine Fisheries' records on shellfish area closures and openings cover a period from April 27 - August 19, 2005.

${ }^{5}$ Maine's estimate was based on 640 shellfish harvesters, 25 shellfish aquaculturists, and 40 boat based shellfish fishermen. For the total impact, a multiplier of 3.0 or 4.5 was applied to the direct impact (Maine Department of Marine Resources: Commissioner George D. Lapointe's letter to NOAA NMFS Regional Director Pat Kurkul on June 21, 2006). Massachusetts' estimate was based on 1,700 shellfish fishermen, 241 shellfish aquaculture growers, and 40 boat based shellfish fisherman. A multiplier of 4.5 was used to estimate the total impact (Massachusetts Executive Department: Governor Mitt Romney's letter to US Commerce Secretary Carlos M. Gutierrez on June 10, 2006).
} 


\section{Methods}

A correct measure of HAB impact should be based on a comparison of two scenarios: with and without the HAB event. Suppose that the net economic benefit of an industry $(\Pi)$ can be measured (e.g., net revenue from fishing). Let $A$ and $B$ refer to the net economic benefits with- and without-HABs; then the economic damage of a red tide event is the difference between these benefits $(\Delta \Pi)$ :

$$
\Delta \Pi=\Pi_{A}-\Pi_{B}
$$

Here we examine changes in the value and quantity of shellfish landings with and without red tide. $\Pi_{A}$ represents the actual harvest value in 2005 and $\Pi_{B}$ is the baseline harvest value. ${ }^{6}$ Because shellfish closures lead to harvest losses, $\Delta \Pi$ should be strictly negative. To develop a more rigorous analysis of the effects of HAB on quantity and value of shellfish landings and to identify broader market effects on shellfish supply channels and prices, we construct regression models using time series data for each of these variables separately. Let $y$ be the dependent variable (e.g., harvest quantity or imports). We model $y$ as:

$$
y=\alpha_{0}+\sum_{i=1}^{11} \alpha_{i} M_{i}+\alpha_{12} t+\alpha_{13} t^{2}+\alpha_{14} D+\varepsilon
$$

where $\alpha_{0}$ through $\alpha_{14}$ are coefficients and $\varepsilon$ is an error term. $M_{i}$ is the dummy variable for month $i, D$ is the dummy variable for red tide (e.g., $D$ represents a three-month period from April to June), and $t$ is time (i.e., year). Thus, changes in $y$ reflect a combination of seasonal fluctuations, linear and nonlinear time trends, and the red tide event.

\footnotetext{
${ }^{6}$ We examine gross values (price times quantity of fish landed). We do not examine net values because of the lack of data on fishing costs in the shellfish sector. If costs are close to revenue there is little welfare impact.
} 
The concept of our analysis is essentially the same as an event study that measures the impact of a specific event on the value of a firm by comparing the "normal" and "abnormal” returns using financial market data (Knapp 1990; MacKinlay 1997; Salin and Hooker 2001).

\section{Data and Results}

For our study, we compiled shellfish data from 1990 to 2005 from several sources, including value and quantity of landings of four shellfish species: quahog (i.e. hard shell clams), softshell clam, mussel, and oyster from the National Marine Fisheries Service (NMFS); shellfish landings data from the Massachusetts Division of Marine Fisheries; shellfish import data from the US Census Bureau; and wholesale price data from the New York Fulton Fish Market. While the import and wholesale price data are mostly complete, the landing statistics are of varying levels of completeness, depending on geographical location, time (i.e., year or month), and species.

\subsection{Harvest Losses in Maine}

NMFS data on monthly shellfish landings in Maine are mostly complete from 1990 to 2005, especially for softshell clams, the dominant species, and mussels. On average, the two species account for over $90 \%$ of annual total value of shellfish landings in Maine. As noted, the red tide impact on the shellfish industry is estimated by comparing the 2005 monthly quantity and value of landings with corresponding baseline quantity and value of non-HAB years.

Although the idea is straightforward, actual construction of the baseline is not. First, the level of shellfish landings may exhibit considerable fluctuations over time due to changes in stock abundance and fishing effort, as well because of other market and 
environmental factors. As depicted in Figure 2, softshell clam landings in Maine were significantly higher in the 1970s than in recent decades. If one used the 1970s' baseline, the impact of red tide would be exaggerated. In addition, seasonal cycles occur in the harvest of many shellfish species (Figure 3). A baseline constructed with annual statistics masks this seasonality and may cause biases in impact estimates.

From Figures 2 and 3, we see that shellfish landings in Maine from 2000 to 2004 were relatively stable with seasonal fluctuations. To capture the seasonal cycle, we use average monthly landings as the baseline for a non-HAB year. Table 1 presents the baseline versus 2005 landings for softshell clams and mussels. As shown in Table 1 and Figure 4, the softshell clam peak harvest season is from May to August. Considerable declines in the quantity of landings occurred from April to August of 2005 with the largest drops of 737 thousand pounds (46\%) and 715 thousand pounds (40\%) in May and June, respectively. The effect of red tide on landings of mussels is also is noticeable from April to June, although much less pronounced (Figure 5). Compared with softshell clam landings, mussel harvests do not exhibit a strong seasonal trend. Also shown in Figures 4 and 5 are the 1990-2004 average monthly harvest levels, which clearly illustrate that estimates of HAB impacts are affected by the selection of specific baselines.

Using the 2000-2004 average as the baseline, we calculate the direct effect of the 2005 red tide event as the sum of lost revenues during HAB-affected months (AprilAugust). The direct impacts include \$2 million in lost revenues in the softshell clam fishery and close to $\$ 400$ thousand in lost revenues in the mussel fishery (see Table 1). 
Annual variations in landings due to changes in species stocks and fishing effort may mask the losses due to the red tide event. ${ }^{7}$ Similarly, observed reductions in catch during a HAB-period may be driven mostly by the annual variations. To examine the statistical significance of red tide impacts on shellfish landings, we model softshell clam landings as a function of seasonal fluctuations, linear and nonlinear time trends, and the red tide event. The model specification in equation (2) was used to estimate quantity and value in two separate regressions, using data from 1990 to $2005 .^{8}$ Results of YuleWalker estimates ${ }^{9}$ are summarized in Table 2. Strong seasonality in harvest levels is highlighted by the magnitude and statistically significant coefficients for May through August in both the quantity and value models. The red tide dummy (for April, May, and June of 2005) is negative and significant in the quantity model. Although the negative sign for the coefficient of the red tide dummy is as expected, the coefficient is not statistically significant in the value model. This may be attributable to HAB-induced price changes, a point we will explore below in Section 4.4 .

\subsection{Harvest Losses in Massachusetts}

Monthly shellfish landings data in Massachusetts are unavailable due to the state’s “less-than-perfect” landing reporting system. ${ }^{10}$ In our study, we combine annual harvest data from NMFS and the Massachusetts Division of Marine Fisheries (DMF).

\footnotetext{
${ }^{7}$ Annual variations may also be caused by shellfish closures at isolated locations due to various small scale HABs, heavy rainfalls, and other pollution events. Localized closures may also be part of an overall management strategy. Because these events are relatively frequent and small in scale, they cannot be separated from the baseline with available data.

${ }^{8}$ In the regressions, $y=$ quantity of landings in millions of pounds and value of landings in millions of dollars, respectively (see Note 2 under Table 2).

${ }^{9}$ Estimates of an autoregressive error model corrected for 3rd order autocorrelation.

${ }^{10}$ Personal communications with David Whittaker of the Massachusetts Division of Marine Fisheries on June 16, 2005.
} 
Specifically, the 1996-2000 data were from DMF and data for other years from NMFS.

As shown in Table 3, data from the two sources appear consistent.

Because much of the data in 2001-2004 are missing, we constructed two alternative baselines: the 1996-1999 average and the 1990-2004 average. In both cases, the negative impacts of the red tide event in 2005 are evident, as indicated by reductions in quahog, softshell clam, and mussel landings. However, the oyster fishery does not appear to have been affected ${ }^{11}$ (see the two rows labeled Change ${ }^{\mathrm{I}}$ and Change ${ }^{\mathrm{II}}$ in Table 3). The most significant difference between the two baselines is the considerably higher level of mussel landings. Note that the NMFS records of mussel harvests in 1990-1993 are much larger than those in subsequent years (top of the column labeled Mussel in Table 3). This leads to a much greater impact estimate for mussels (Table 3 and Figure $6)$.

Using Massachusetts shellfish prices in 2005, we estimate the value of lost harvests. As shown in Table 4, most significant losses in revenues occurred in the quahog and softshell clam fisheries. The total direct impact on the commercial shellfish industry in Massachusetts may be as high as $\$ 18$ million. Because of data limitations, especially the missing data in 2001-2004, we should interpret the impact estimate as an upper-bound. This estimate is consistent with the estimate of $\$ 10.26$ million direct by Hickey and Whittaker (2006).

NMFS data for 1990-1994 include monthly mussel landings in some Massachusetts counties, which enable us to calculate monthly shares. We construct a

\footnotetext{
${ }^{11}$ This could be a result of increased harvests in both pre- and post-red tide periods. Fishers could pull most oysters out before the HAB, or they could leave them in place until the shellfish beds reopened. We cannot tell what happened with annual data.
} 
monthly mussel landing baseline using those monthly shares and the 1996-1999 annual

average. As depicted in Figure 7, the red tide caused noticeable declines in harvest from April to July with a nearly complete loss in June.

\subsection{Imports to New England}

To assess the broader market effects of the 2005 red tide event and to identify alternative market supply channels, we examine live and fresh shellfish imports to New England from Canada using 1990-2005 data from the US Census Bureau. Specifically, we estimate equation (2) using imports as a dependent variable. ${ }^{12}$ Results of separate estimations for quantity and value are summarized in Table 5. The results indicate that the models fit the data well with R-squares above 0.9. Shellfish imports also exhibit strong seasonal cycles with higher levels in the summer and lower levels in January through March. Import quantities have been increasing since 1990.

As suggested by the positive and statistically significant coefficients for the red tide dummies in both the quantity and value models, the red tide event in 2005 probably led to an increase in imports to fill the supply-demand gap resulting from declines in local harvests. This implies that the indirect impacts of a HAB-event on the seafood industries (e.g., seafood retails and restaurants) may be partially offset by rising supplies from other market channels. Imports flow into the same processing and distribution channels as raw product, thereby ameliorating indirect and induced effects in these

\footnotetext{
${ }^{12}$ In the regressions, $y=$ quantity of imports in millions of kilograms and value of imports in millions of dollars, respectively (see Note 3 under Table 5).
} 
sectors. In other words, multipliers of 3.0 or 4.5 , such as those used by the states of Maine and Massachusetts to estimate total impacts, may be excessive ${ }^{13}$.

\subsection{Spatial and Temporal Price Effects}

Finally, we examine the broader market effects of the 2005 red tide event by assessing spatial and temporal changes in the ex-vessel price of softshell clams in Maine and in the wholesale price of softshell clams on the Fulton Fish Market in New York City. Other than occasional supplies from Massachusetts and Maryland, Maine has been the major supplier of softshell clams to the New York wholesale market. Figure 8 depicts two baseline prices (i.e., 1990-2004 average and 2000-2004 average) and the wholesale price in 2005 on the Fulton Fish Market. An interesting finding is that the price was higher than normal during the early stages of the red tide event (May and June), possibly due to supply shortages from Maine, and lower than normal during the later stage of the event (August through October), possibly because of consumer concerns of seafood quality resulting from negative media publicity, as discussed by Wessells et al. (1995) and Whitehead et al. (2003) in their case studies. Another possible cause for the price drop is that when the New York market expected supply to be limited all summer, wholesalers switched to other sources or to other shellfish species to ensure stable supply.

As a further analysis, we develop four price models with the same specification as equation (2), with the dependent variable $y=$ softshell clam prices in Maine and New York, respectively. As shown in Table 6, the dependent variables in Models A and B are Maine ex-vessel softshell clam prices from the NMFS dealer data and the dependent variables in Models C and D are New York wholesale prices from the Fulton Fish

\footnotetext{
${ }^{13}$ These multipliers may also be excessive because shellfish harvesting uses very low levels of purchased inputs and product flows from harvester to consumer with relatively little value added at either the wholesale or retail level.
} 
Market. Results of all four models suggest strong seasonal cycles in softshell clam prices at both locations, with higher prices in summer (July, August, and September) and lower prices in spring (March, April, and May). Overall, prices have been declining since 1990, as indicated by the negative signs and statistically significant coefficients for the time trend (i.e., Year).

We used a dummy variable, Redtide ${ }^{\mathrm{I}}$, in Models A and C, to assess the price effect during the early stage of the HAB event. The coefficients for the dummy in both models are positive, suggesting a price increase. However, only the increase in New York City is statistically significant. Similarly, we included dummy variable, Redtide ${ }^{\text {II }}$, in Models B and D to examine the price effect during the later stage of the event. The estimation results indicate statistically significant price drops in both Maine and New York City. Generally, the results, particularly those of the Fulton models, suggest a temporal effect on softshell clam prices that may be a function of information dissemination: in the early stage of the red tide event, there was no significant reduction in shellfish demand; however, as the negative information about seafood quality disseminated among consumers, the reduction in demand became more evident. It is also likely that consumers switched to substitute seafoods from other supply sources.

\section{Conclusions}

Existing impact assessments of HAB events are often rough estimates based on limited observation or hypothetical events. In most cases, we do not have a good understanding of the economic effects of red tide events. From a management perspective, however, it is important to measure the scale of the economic costs to society of HAB events. 
We develop estimates of direct economic impacts of the 2005 event on commercial shellfish fisheries in Maine and Massachusetts using methods that are consistent with economic theory and data from NMFS, DMF, and other sources. Our results indicate that the low-end estimate for total direct impacts in Maine was \$2.4 million including lost revenues in the softshell clam and mussel fisheries. The total direct impacts on commercial shellfish industry in Massachusetts may be as high as \$18 million. These estimates are actually larger than the estimate of direct harvest loss of \$10.26 million reported in Hickey and Whittaker (2006). However, because of serious data limitations, the estimated direct impact on Massachusetts harvesters should be viewed with caution. To improve estimates of HAB impacts in Massachusetts, it will be essential to construct a baseline of monthly shellfish landings so that HAB impact assessments may focus on the relevant months. For the same reason, daily data would further improve the precision of our future estimates. We have shown that impact estimates are affected by baseline values of non-HAB years. An accurate impact estimate requires a relatively stable baseline using data from recent years.

We have identified two broader effects of the 2005 red tide event on shellfish market. First, the event led to an increase in shellfish imports to fill the supply-demand gap resulting from declines in local harvests. This implies that indirect impacts of a HAB-event on the seafood industries may be partially mitigated by rising supplies from alternative market channels. Second, we have shown that HAB impacts on softshell clam prices are spatially linked: the shellfish closures in Maine may result in price changes in New York. 


\section{References}

Anderson, D.M., B.A. Keafer, D.J. McGillicuddy Jr., M.J. Mickelson, K.E. Keay, P.S. Libby, J.P. Manning, C.A. Mayo, D.K. Whittaker, J.M. Hickey, R. He, D.R. Lynch and K.W. Smith. 2005. Initial observations of the 2005 Alexandrium fundyense bloom in southern New England: general patterns and mechanisms. Deep-Sea Research II 52:2856-2876.

Damery, D.T. and P.G. Allen. 2004. An Economic Valuation of Recreational Shellfishing on Cape Cod. Working Paper No. 2004-10. Department of Resource Economics, University of Massachusetts, Amherst, MA.

Hickey, J.M. and D.K. Whittaker. 2006. Massachusetts Red Tide Response. Presentation at Symposium on the Alexandrium fundyense Red Tide of 2005. April 18. MIT, Cambridge, MA.

Hoagland, P., D.M. Anderson, Y. Kaoru and A.W. White. 2002. The economic effects of harmful algal blooms in the United States: estimates, assessment issues, and information needs. Estuaries 25(4b):819-837.

Hoagland, P. and S. Scatasta. 2006. The economic effects of harmful algal blooms. In Ecology of Harmful Algae, E. Graneli and J.T. Turner (Eds.) Spring-Verlag, Berlin.

Knapp, W. 1990. Event analysis of air carrier mergers and acquisitions. Review of Economics and Statistics 72(4):703-707.

MacKinlay, A.C. 1997. Event studies in economics and finance. Journal of Economic Literature 35(1):13-39.

Salin, V. and N.H. Hooker. 2001. Stock market reaction to food recalls. Review of Agricultural Economics 23(1):33-46.

Vakalopoulos, C.C., M.J. Mickelson and J. Pederson. 2006. Summary of Symposium on the Alexandrium fundyense Red Tide of 2005. MIT Sea Grant Report. MITSG 06-7, 9pp. Cambridge, MA.

Wessells, C.R., C.J. Miller and P. M. Brooks. 1995. Toxic algae contamination and demand for shellfish: a case study of demand for mussels in Montreal. Marine Resource Economics 10:143-159.

Whitehead J.C., T.C. Haab and G.R. Parsons. 2003. Economic effects of Pfiesteria. Ocean \& Coastal Management 46(9-10):845-858. 
Table 1. Changes in Monthly Landings of Softshell Clams and Mussels in Maine: Baseline versus 2005

\begin{tabular}{|c|c|c|c|c|c|c|c|c|c|c|c|c|}
\hline \multirow{3}{*}{ Month } & \multicolumn{6}{|c|}{ Softshell Clam } & \multicolumn{6}{|c|}{ Mussel } \\
\hline & \multicolumn{3}{|c|}{ Quantity (live weight lb) } & \multicolumn{3}{|c|}{ Value $(2005 \$)$} & \multicolumn{3}{|c|}{ Quantity (live weight lb) } & \multicolumn{3}{|c|}{ Value $(2005 \$)$} \\
\hline & Baseline & 2005 & Change & Baseline & 2005 & Change & Baseline & 2005 & Change & Baseline & 2005 & Change \\
\hline Jan & 421,786 & 331,291 & $-90,495$ & 671,345 & 544,038 & $-127,307$ & $1,404,327$ & $1,142,185$ & $-262,142$ & 229,412 & 120,343 & $-109,069$ \\
\hline Feb & 500,524 & 383,211 & $-117,313$ & 682,247 & 644,882 & $-37,365$ & $1,499,994$ & $2,422,161$ & 922,167 & 262,105 & 314,699 & 52,594 \\
\hline Mar & 922,248 & 852,365 & $-69,883$ & 930,249 & $1,022,478$ & 92,229 & $2,446,115$ & $2,049,061$ & $-397,054$ & 339,492 & 236,161 & $-103,331$ \\
\hline Apr & $1,139,308$ & 767,881 & $-371,427$ & $1,209,859$ & 982,251 & $-227,608$ & $1,777,367$ & $1,465,505$ & $-311,862$ & 244,309 & 152,807 & $-91,502$ \\
\hline May & $1,606,325$ & 869,519 & $-736,806$ & $1,712,933$ & $1,273,746$ & $-439,187$ & $1,822,645$ & $1,513,803$ & $-308,842$ & 288,383 & 171,194 & $-117,189$ \\
\hline Jun & $1,766,825$ & $1,052,240$ & $-714,585$ & 2,391,666 & $1,692,350$ & $-699,316$ & $2,204,831$ & $2,055,944$ & $-148,887$ & 369,545 & 264,551 & $-104,994$ \\
\hline Jul & $1,693,384$ & $1,568,641$ & $-124,743$ & $2,839,816$ & $2,734,690$ & $-105,126$ & $1,843,816$ & $1,807,628$ & $-36,188$ & 289,139 & 268,018 & $-21,121$ \\
\hline Aug & $1,515,860$ & $1,376,220$ & $-139,640$ & $3,089,636$ & $2,480,192$ & $-609,444$ & $2,141,236$ & $2,080,840$ & $-60,396$ & 365,913 & 308,974 & $-56,939$ \\
\hline Sep & 699,336 & 738,142 & 38,806 & $1,254,658$ & $1,132,334$ & $-122,324$ & $1,753,300$ & $1,529,706$ & $-223,594$ & 436,615 & 215,848 & $-220,767$ \\
\hline Oct & 639,354 & 184,103 & $-455,251$ & $1,022,799$ & 280,199 & $-742,600$ & $1,454,013$ & 487,133 & $-966,880$ & 307,928 & 107,686 & $-200,242$ \\
\hline Nov & 499,969 & 486,759 & $-13,210$ & 719,719 & 748,020 & 28,301 & $1,502,896$ & $1,490,040$ & $-12,856$ & 236,756 & 223,697 & $-13,059$ \\
\hline Dec & 464,365 & 488,231 & 23,866 & 700,690 & 650,981 & $-49,709$ & 2,146,182 & $1,629,618$ & $-516,564$ & 353,471 & 240,010 & $-113,461$ \\
\hline $\begin{array}{c}\text { Annual } \\
\text { Sum }\end{array}$ & $11,869,284$ & $9,098,603$ & $-2,770,681$ & $17,225,617$ & $14,186,161$ & $-3,039,456$ & 21,996,722 & $19,673,624$ & $-2,323,098$ & $3,723,068$ & 2,623,988 & $-1,099,080$ \\
\hline $\begin{array}{c}\text { Apr-Aug } \\
\text { Sum }\end{array}$ & 7,721,702 & $5,634,501$ & $-2,087,201$ & $11,243,910$ & $9,163,229$ & $-2,080,681$ & $9,789,895$ & $8,923,720$ & $-866,175$ & $1,557,289$ & $1,165,544$ & $-391,745$ \\
\hline
\end{tabular}

Note: All baselines are constructed by computing the average values for each month using data from 2000 to 2004 . 
Table 2. Maine Softshell Clam Landings (Yule-Walker Estimates)

\begin{tabular}{lcc}
\hline Variable & $\begin{array}{c}\text { Quantity } \\
\text { Coefficient } \\
\text { (t-value) }\end{array}$ & $\begin{array}{c}\text { Value } \\
\text { Coefficient } \\
\text { (t-value) }\end{array}$ \\
\hline Intercept & 8.3602 & 62.3930 \\
& $(0.53)$ & $(1.90)$ \\
M1 & -0.0498 & -0.0377 \\
& $(-0.66)$ & $(-0.30)$ \\
M2 & -0.0084 & -0.0303 \\
& $(-0.11)$ & $(-0.21)$ \\
M3 & 0.4034 & 0.3241 \\
& $(4.67)^{* * *}$ & $(1.93)^{*}$ \\
M4 & 0.6108 & 0.4846 \\
& $(6.91)^{* * *}$ & $(2.75)^{* * *}$ \\
M5 & 1.0240 & 1.0041 \\
& $(11.33)^{* * *}$ & $(5.56)^{* * *}$ \\
M6 & 1.2963 & 1.7087 \\
& $(14.35)^{* * *}$ & $(9.42)^{* * *}$ \\
M7 & 1.1557 & 2.0618 \\
& $(12.89)^{* * *}$ & $(11.51)^{* * *}$ \\
M8 & 1.0750 & 2.2284 \\
& $(12.29)^{* * *}$ & $(12.75)^{* * *}$ \\
M9 & 0.4420 & 0.8399 \\
& $(5.13)^{* * *}$ & $(5.03)^{* * *}$ \\
M10 & 0.1804 & 0.2992 \\
RW & $(2.36)^{* *}$ & $(2.05)^{* *}$ \\
M11 & 0.0316 & 0.0336 \\
Year & $(0.42)$ & $(0.27)$ \\
& -0.1745 & -1.2901 \\
& $(-0.53)$ & $(-1.91)^{*}$ \\
& 0.0009 & 0.0067 \\
& $(0.57)$ & $(1.94)^{*}$ \\
& -0.5237 & -0.5100 \\
& $(-2.96)^{* * *}$ & $(-1.47)$ \\
\hline
\end{tabular}

Notes: $(1)^{*},{ }^{* *}$, and ${ }^{* * *}$ against the reported coefficients denote significance at $10,5,1 \%$ levels, respectively.

(2) Quantity in live weight (millions of pounds) and value in millions of 2005 dollars.

(3) Redtide: Dummy represents April, May, and June.

(4) Both model corrected for 3rd order autocorrelation. 
Table 3. Annual Shellfish Landings in Massachusetts

\begin{tabular}{ccccc}
\hline Year & Quahog & Softshell Clam & Mussel & Oyster \\
\hline 1990 & $7,702,387$ & $3,870,516$ & $30,647,357$ & 470,820 \\
1991 & $7,518,091$ & $5,628,854$ & $31,547,353$ & 498,921 \\
1992 & $7,560,130$ & $6,956,255$ & $32,285,710$ & 732,586 \\
1993 & $8,249,135$ & $6,609,711$ & $10,095,052$ & 636,149 \\
1994 & - & - & - & - \\
1995 & - & - & - & - \\
1996 & $6,968,457$ & $9,874,560$ & 939,565 & 264,900 \\
1997 & $6,208,406$ & $11,548,440$ & 941,710 & 721,150 \\
1998 & $6,323,778$ & $10,962,000$ & $1,512,670$ & 798,422 \\
1999 & $7,597,341$ & $7,174,088$ & $1,975,710$ & 689,710 \\
2000 & $3,147,697$ & $3,073,408$ & 41,625 & 515,506 \\
2001 & - & - & - & - \\
2002 & $11,129,220$ & - & - & - \\
2003 & - & - & - & - \\
2004 & - & - & - & 132,135 \\
2005 & $1,541,086$ & $2,458,602$ & $1,151,294$ & $1,285,024$ \\
\hline Average & & & & \\
$(1996-1999)$ & $6,774,496$ & $9,889,772$ & $1,342,414$ & 618,546 \\
Change & $-5,233,410$ & $-7,431,170$ & $-191,120$ & 666,479 \\
\hline Average & & & & \\
$(1990-2004)$ & $7,240,464$ & $7,299,759$ & $12,220,750$ & 546,030 \\
Change ${ }^{\text {II }}$ & $-5,699,378$ & $-4,841,157$ & $-11,069,456$ & 738,994 \\
\hline
\end{tabular}

Notes: (1) All units are live weight in pounds.

(2) - data are incomplete or unavailable.

(3) 1996-2000 data are from Massachusetts Division of Marine Fisheries (Massachusetts Shellfish Statistics, 1996-2000, Based on Reports from Town Shellfish Officers, Total Commercial Landings. http://www.mass.gov/dfwele/dmf/commercialfishing/5yr_shoff.pdf). Data in other years are from NMFS.

(4) Change ${ }^{I}$ is the differential between 2005 landings and the 1996-1999 average.

(5) Change ${ }^{\text {II }}$ is the differential between 2005 landings and the 1990-2004 average. 
Table 4. Changes in Annual Shellfish Landings in Massachusetts:

\section{Baseline versus 2005}

\begin{tabular}{|c|c|c|c|c|c|}
\hline Species & $\begin{array}{c}\text { Quantity } \\
\text { Change }^{\text {I }} \\
\text { (lb) }\end{array}$ & $\begin{array}{c}\text { Quantity } \\
\text { Change }^{\text {II }} \\
\text { (lb) }\end{array}$ & $\begin{array}{l}\text { Price } \\
(\$ / \mathrm{lb})\end{array}$ & $\begin{array}{c}\text { Value Change } \\
(2005 \$)\end{array}$ & $\begin{array}{c}\text { Value Change }^{\text {II }} \\
(2005 \$) \\
\end{array}$ \\
\hline Quahog & $-5,233,410$ & $-5,699,378$ & 1.08 & $-5,651,140$ & $-6,154,303$ \\
\hline Softshell Clam & $-7,431,170$ & 157 & 1.62 & $-12,063,910$ & ,231 \\
\hline Mussel & $-191,120$ & $-11,069,456$ & 0.15 & $-29,532$ & $-1,710,452$ \\
\hline Sum & $-12,855,699$ & $-21,609,992$ & & $-17,744,582$ & $-15,723,986$ \\
\hline
\end{tabular}

Notes: (1) Quantity Change ${ }^{\mathrm{I}}$ and Quantity Change ${ }^{\mathrm{II}}$ are from Table 3.

(2) Prices are in 2005 dollars per pound (live weight) and computed using NMFS 2005 data. 
Table 5. New England Shellfish Imports (Yule-Walker Estimates)

\begin{tabular}{lcc}
\hline Variable & $\begin{array}{c}\text { Quantity } \\
\text { Coefficient } \\
(\mathrm{t}-\mathrm{value})\end{array}$ & $\begin{array}{c}\text { Value } \\
\text { Coefficient } \\
(\mathrm{t}-\mathrm{value})\end{array}$ \\
\hline Intercept & -22.7017 & -22.7784 \\
& $(-2.28)^{* *}$ & $(-0.75)$ \\
M1 & -0.1596 & -0.4310 \\
& $(-7.16)^{* * *}$ & $(-4.15)^{* * *}$ \\
M2 & -0.1378 & -0.4033 \\
& $(-4.53)^{* * *}$ & $(-3.06)^{* * *}$ \\
M3 & -0.0898 & -0.3128 \\
& $(-2.51)^{* *}$ & $(2.09)^{* *}$ \\
M4 & -0.0651 & -0.0548 \\
& $(-1.66)^{*}$ & $(-0.34)$ \\
M5 & 0.0529 & 0.6192 \\
& $(1.29)$ & $(3.69)^{* * *}$ \\
M6 & 0.2228 & 1.6108 \\
& $(5.36)^{* * *}$ & $(9.51)^{* * *}$ \\
M7 & 0.3899 & 2.4589 \\
& $(9.56)^{* * *}$ & $(14.77)^{* * *}$ \\
M8 & 0.4323 & 2.7261 \\
& $(11.10)^{* * *}$ & $(16.94)^{* * *}$ \\
M9 & 0.1732 & 1.5004 \\
& $(4.89)^{* * *}$ & $(10.10)^{* * *}$ \\
M10 & 0.0283 & 0.6430 \\
& $(0.95)$ & $(4.94)^{* * *}$ \\
M11 & -0.0908 & -0.1245 \\
& $(-4.23)$ & $(-1.23)$ \\
Year & 0.4113 & 0.3549 \\
& $(2.01)^{* *}$ & $(0.57)$ \\
Year & -0.0018 & -0.0011 \\
& $(-1.69)^{*}$ & $(-0.34)$ \\
Redtide & 0.1316 & 0.7700 \\
& $(2.02)^{* *}$ & $(2.60)^{* * *}$ \\
\hline Observations & 192 & 192 \\
R & 0.96 & 0.93 \\
DW & 1.93 & 1.99 \\
\hline & & \\
& &
\end{tabular}

Notes: $(1){ }^{*}, * *$, and ${ }^{* * *}$ against the reported coefficients denote significance at $10,5,1 \%$ levels, respectively.

(2) Including clam, mussel, and oyster in live/fresh product forms imported from Canada.

(3) Quantity in millions of kilograms and value in millions of 2005 dollars.

(4) Redtide: Dummy represents April, May, and June.

(5) Quantity and value models corrected for 5th and 4th order autocorrelation, respectively. 
Table 6. Softshell Clam Price in Maine and New York (Yule-Walker Estimates)

\begin{tabular}{|c|c|c|c|c|}
\hline \multirow[t]{2}{*}{ Variable } & \multicolumn{2}{|c|}{$\begin{array}{c}\text { Maine Price } \\
\text { Coefficient } \\
\text { (t-value) }\end{array}$} & \multicolumn{2}{|c|}{$\begin{array}{c}\text { Fulton Price } \\
\text { Coefficient } \\
\text { (t-value) }\end{array}$} \\
\hline & Model A & Model B & Model C & Model D \\
\hline Intercept & $\begin{array}{l}62.6569 \\
(2.47)^{* *}\end{array}$ & $\begin{array}{l}69.8292 \\
(2.64)^{* * *}\end{array}$ & $\begin{array}{c}3631 \\
(1.78)^{*}\end{array}$ & $\begin{array}{l}4463 \\
(2.18)^{* *}\end{array}$ \\
\hline M1 & $\begin{array}{c}0.0683 \\
(1.12)\end{array}$ & $\begin{array}{l}0.0648 \\
(1.09)\end{array}$ & $\begin{array}{l}6.7920 \\
(1.31)\end{array}$ & $\begin{array}{l}6.7357 \\
(1.32)\end{array}$ \\
\hline M2 & $\begin{array}{c}-0.0395 \\
(-0.57)\end{array}$ & $\begin{array}{c}-0.0436 \\
(-0.62)\end{array}$ & $\begin{array}{l}2.8035 \\
(0.46)\end{array}$ & $\begin{array}{l}2.7829 \\
(0.46)\end{array}$ \\
\hline M3 & $\begin{array}{l}-0.2687 \\
(-3.51)^{* * *}\end{array}$ & $\begin{array}{l}-0.2701 \\
(-3.41)^{* * *}\end{array}$ & $\begin{array}{c}-0.6359 \\
(-0.11)\end{array}$ & $\begin{array}{c}-1.0081 \\
(-0.17)\end{array}$ \\
\hline M4 & $\begin{array}{l}-0.3408 \\
(-4.23)^{* * *}\end{array}$ & $\begin{array}{l}-0.3305 \\
(-3.82)^{* * *}\end{array}$ & $\begin{array}{l}-15.2614 \\
(-2.70)^{* * *}\end{array}$ & $\begin{array}{l}-15.7873 \\
(-2.75)^{* * *}\end{array}$ \\
\hline M5 & $\begin{array}{l}-0.2483 \\
(-2.96)^{* * *}\end{array}$ & $\begin{array}{l}-0.2366 \\
(-2.65)^{* * *}\end{array}$ & $\begin{array}{l}-14.8536 \\
(-2.57)^{* *}\end{array}$ & $\begin{array}{l}-13.5594 \\
(-2.37)^{* *}\end{array}$ \\
\hline M6 & $\begin{array}{c}-0.0024 \\
(-0.03)\end{array}$ & $\begin{array}{l}0.0087 \\
(0.10)\end{array}$ & $\begin{array}{c}-3.6545 \\
(-0.61)\end{array}$ & $\begin{array}{c}-2.3734 \\
(-0.40)\end{array}$ \\
\hline M7 & $\begin{array}{c}0.3386 \\
(4.08)^{* * *}\end{array}$ & $\begin{array}{c}0.3548 \\
(3.94)^{* * *}\end{array}$ & $\begin{array}{l}18.4334 \\
(3.23)^{* * *}\end{array}$ & $\begin{array}{l}19.7700 \\
(3.44)^{* * *}\end{array}$ \\
\hline M8 & $\begin{array}{c}0.5670 \\
(7.12)^{* * *}\end{array}$ & $\begin{array}{l}0.5840 \\
(6.74)^{* * *}\end{array}$ & $\begin{array}{l}29.5543 \\
(5.26)^{* * *}\end{array}$ & $\begin{array}{l}30.8398 \\
(5.38)^{* * *}\end{array}$ \\
\hline M9 & $\begin{array}{l}0.2879 \\
(3.79)^{* * *}\end{array}$ & $\begin{array}{l}0.3034 \\
(3.83)^{* * *}\end{array}$ & $\begin{array}{l}22.0127 \\
(3.67)^{* * *}\end{array}$ & $\begin{array}{l}23.4612 \\
(3.87)^{* * *}\end{array}$ \\
\hline M10 & $\begin{array}{l}0.1054 \\
(1.54)\end{array}$ & $\begin{array}{l}0.1051 \\
(1.52)\end{array}$ & $\begin{array}{l}4.8417 \\
(0.80)\end{array}$ & $\begin{array}{l}6.1787 \\
(1.02)\end{array}$ \\
\hline M11 & $\begin{array}{c}-0.0332 \\
(-0.56)\end{array}$ & $\begin{array}{c}-0.0351 \\
(-0.61)\end{array}$ & $\begin{array}{c}-2.8263 \\
(-0.55)\end{array}$ & $\begin{array}{c}-3.5873 \\
(-0.71)\end{array}$ \\
\hline Year & $\begin{array}{l}-1.2715 \\
(-2.44)^{* *}\end{array}$ & $\begin{array}{l}-1.4212 \\
(-2.61)^{* * *}\end{array}$ & $\begin{array}{c}-68.4623 \\
(-1.64)\end{array}$ & $\begin{array}{l}-86.0065 \\
(-2.04)^{* *}\end{array}$ \\
\hline Year $^{2}$ & $\begin{array}{l}0.0066 \\
(2.46)^{* *}\end{array}$ & $\begin{array}{c}0.0074 \\
(2.64)^{* * *}\end{array}$ & $\begin{array}{l}0.3336 \\
(1.55)\end{array}$ & $\begin{array}{l}0.4259 \\
(1.97)^{* *}\end{array}$ \\
\hline Redtide $^{\mathrm{I}}$ & $\begin{array}{l}0.1664 \\
(1.02)\end{array}$ & - & $\begin{array}{l}28.4180 \\
(2.05)^{* *}\end{array}$ & - \\
\hline Redtide $^{\mathrm{II}}$ & - & $\begin{array}{l}-0.2787 \\
(-1.71)^{*}\end{array}$ & (2. & $\begin{array}{l}-32.6579 \\
(-2.64)^{* * *}\end{array}$ \\
\hline Observations & 192 & 192 & 191 & 191 \\
\hline $\mathrm{R}^{2}$ & 0.75 & 0.75 & 0.73 & 0.73 \\
\hline DW & 1.98 & 1.96 & 1.93 & 1.96 \\
\hline
\end{tabular}

Notes: $(1){ }^{*}, * *$, and ${ }^{* * *}$ against the reported coefficients denote significance at $10,5,1 \%$ levels, respectively.

(2) Fulton price: Wholesale prices on New York Fulton Fish Market.

(3) Units: Marine price in 2005 \$/pound (live weight) and Fulton price in 2005 \$/Maine bushel.

(4) Redtide ${ }^{\mathrm{I}}$ : Maine model dummy represents April, May, and June and Fulton model dummy represents May and June.

(5) Redtide ${ }^{\text {II }}$ : Maine model dummy represents July, August, and September and Fulton model dummy represents July, August, September, and October.

(6) Model A corrected for $8^{\text {th }}$ order autocorrelation and Models B, C, and D corrected for $12^{\text {th }}$ order autocorrelation. 
Figure 1. Sequence of Shellfish Closures Due to Red Tide in 2005

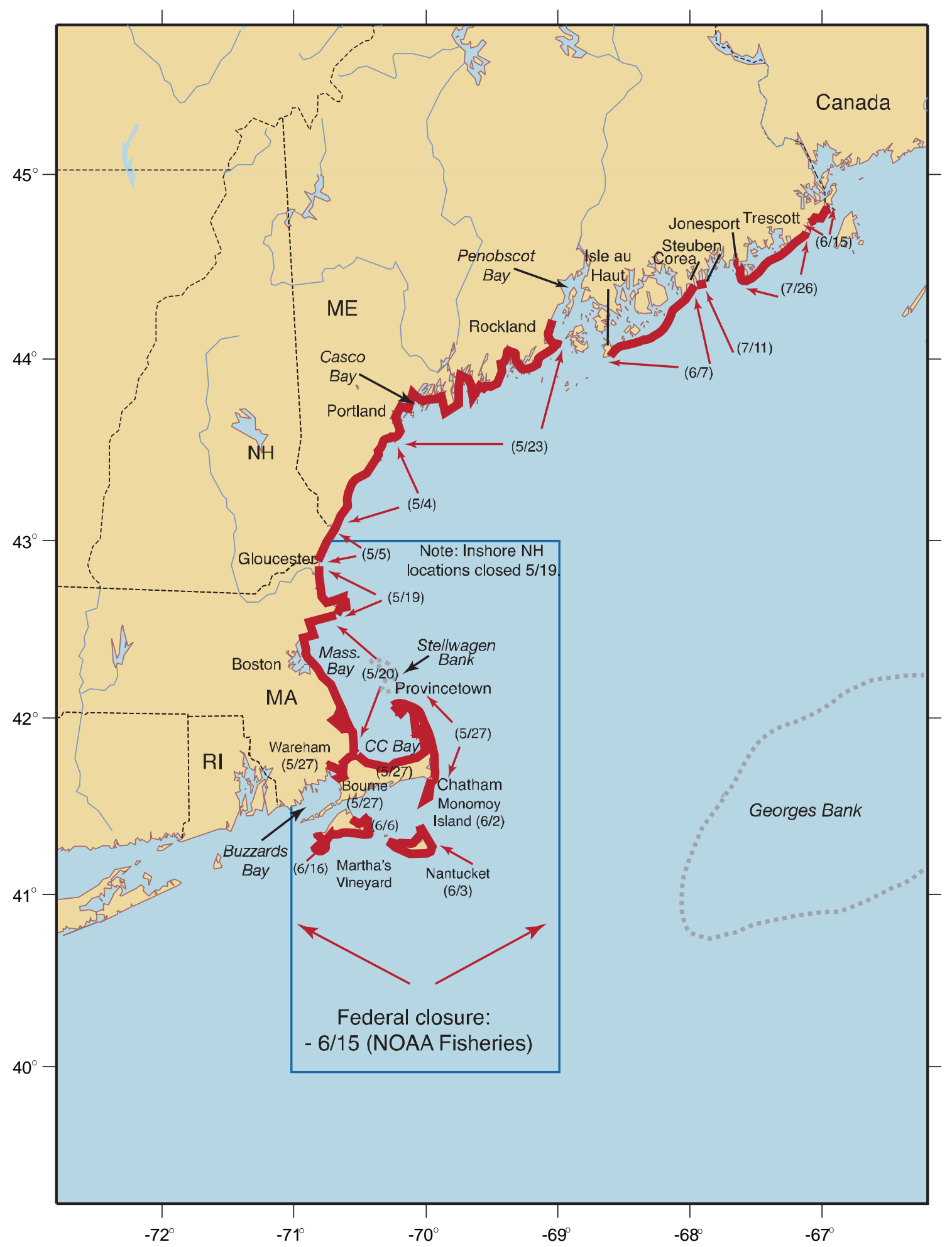

Source: Anderson et al. (2005). 
Figure 2. Annual Softshell Clam Landings in Maine, 1950-2005

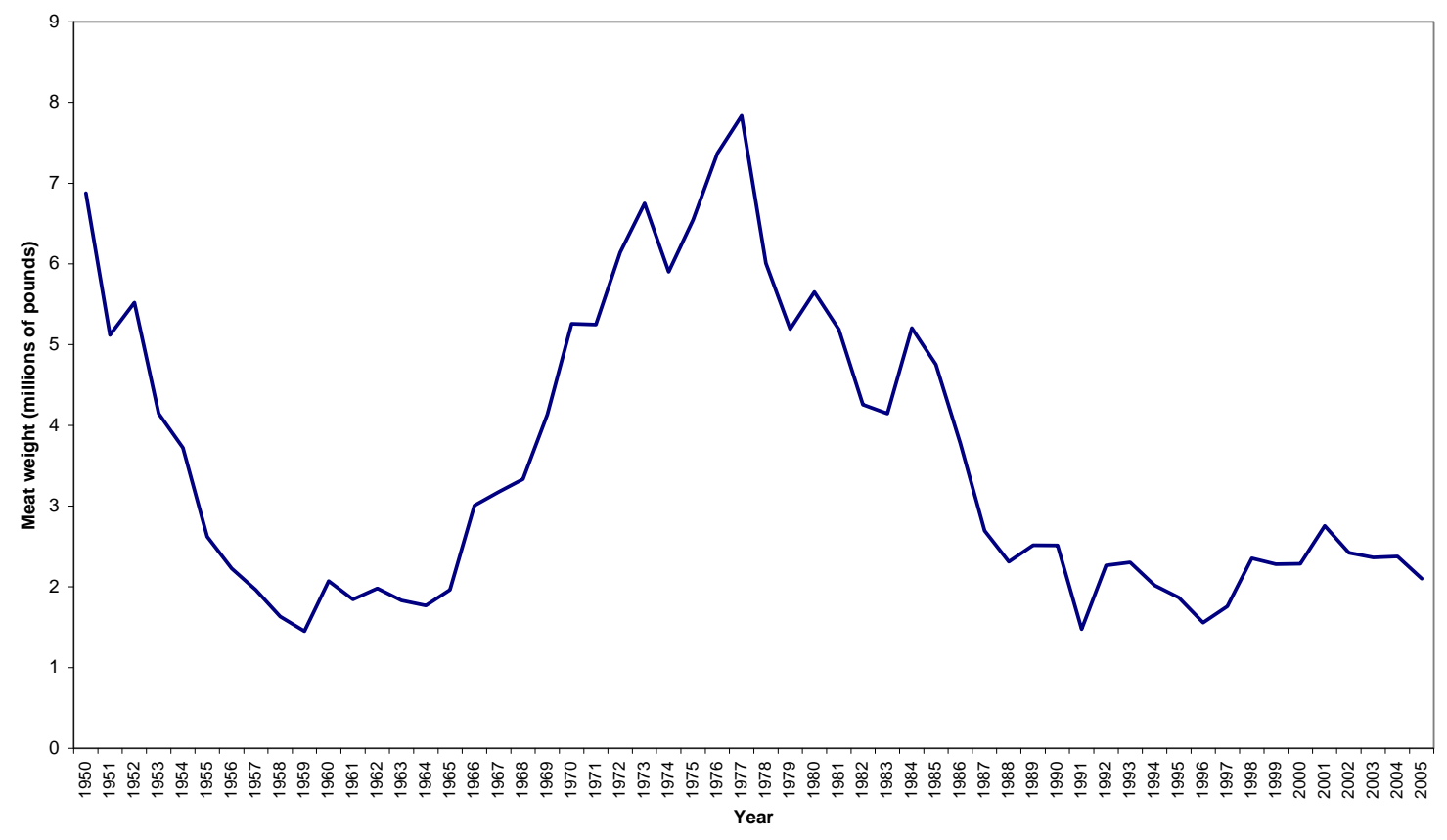

Source: Maine Department of Marine Resources. Historical Maine Softshell Clam Landings (http://www.maine.gov/dmr/commercialfishing/softshellclam.mht). 
Figures 3. Monthly Shellfish Landings in Maine, 1990-2005

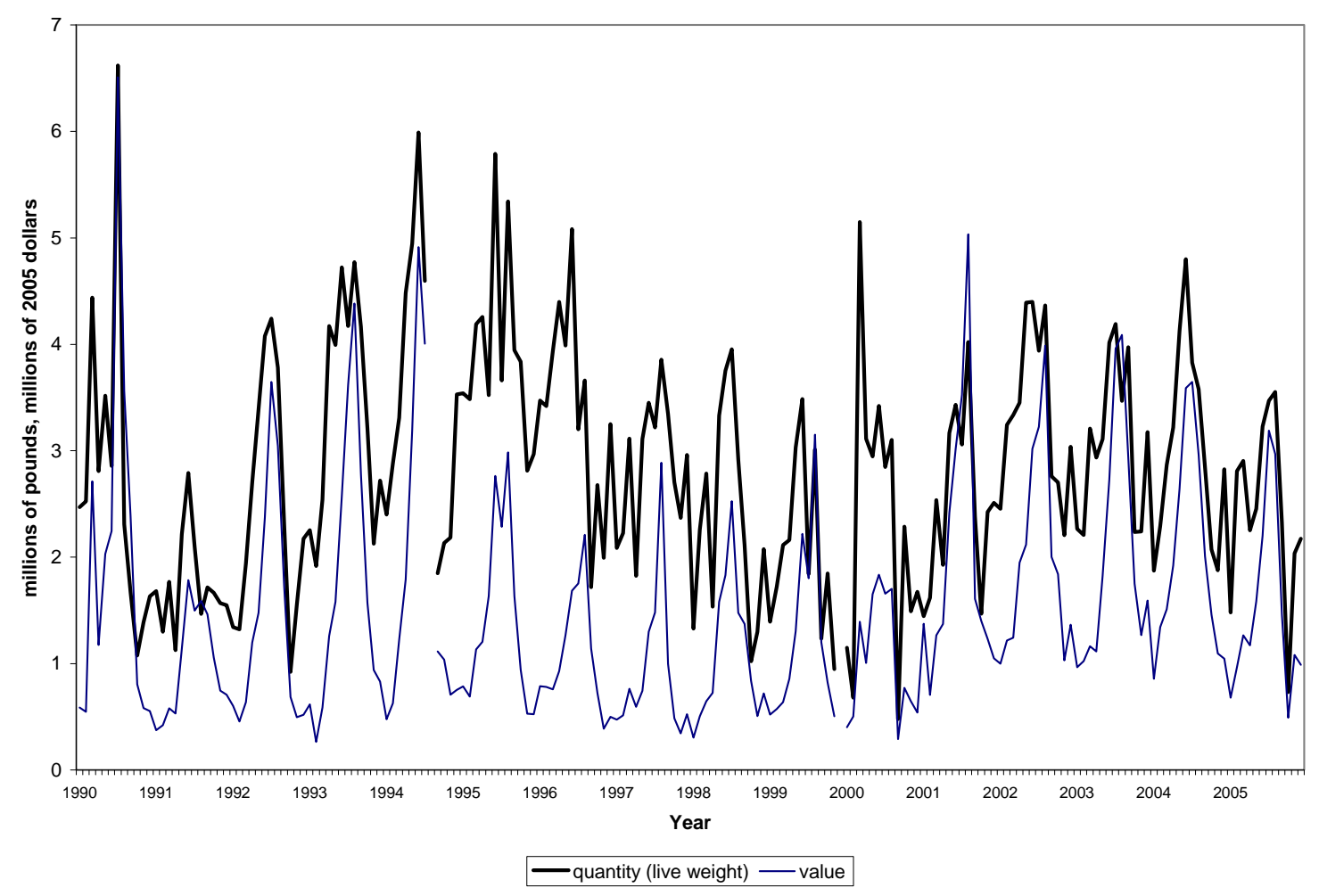

Note: Figures include four shellfish species: quahog, softshell clam, mussel, and oyster. 
Figure 4. Monthly Softshell Clam Landings in Maine: Baseline versus 2005

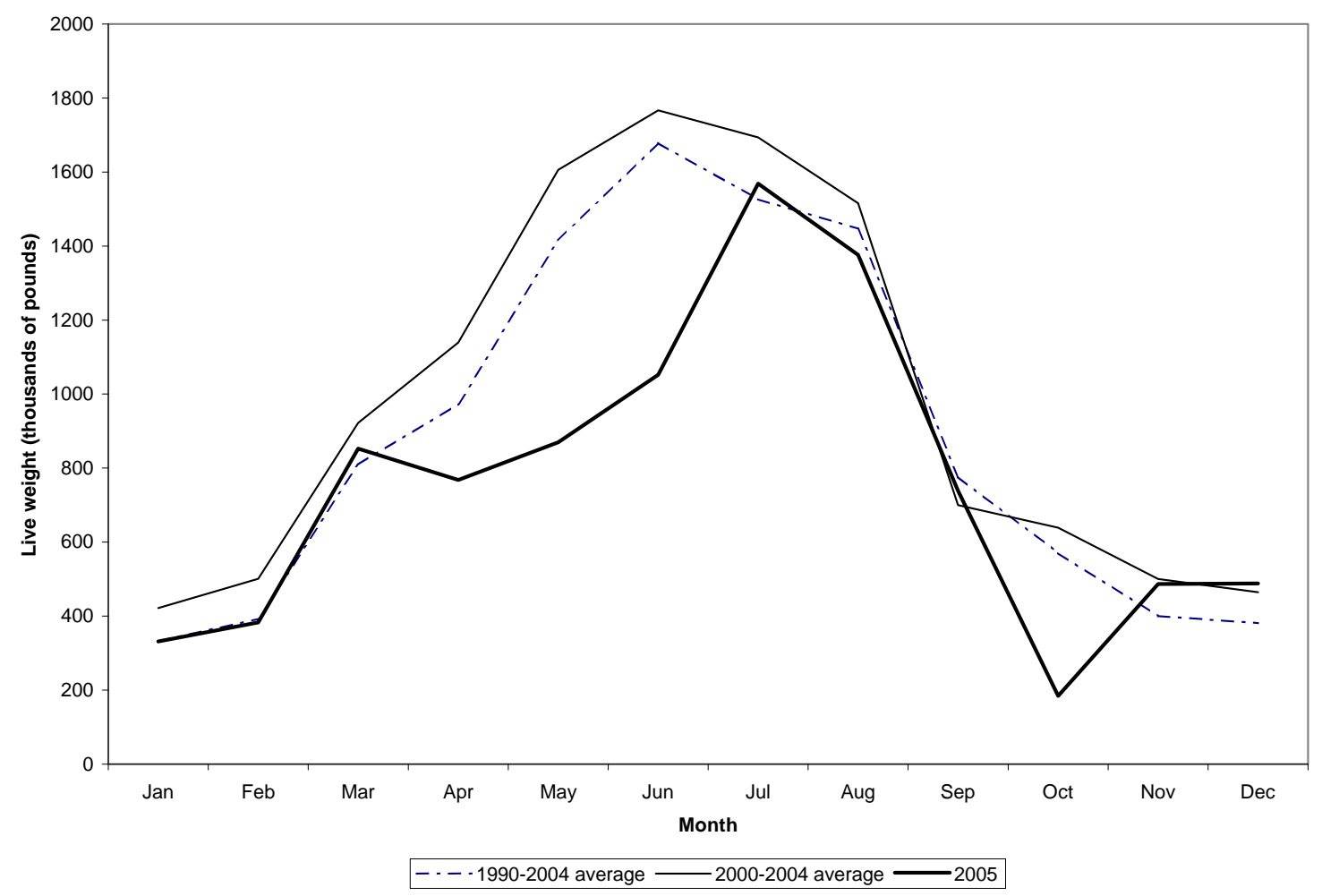

Note: 1990-2004 average excludes 1993 (when red tide also occurred). 
Figure 5. Monthly Mussel Landings in Maine: Baseline versus 2005

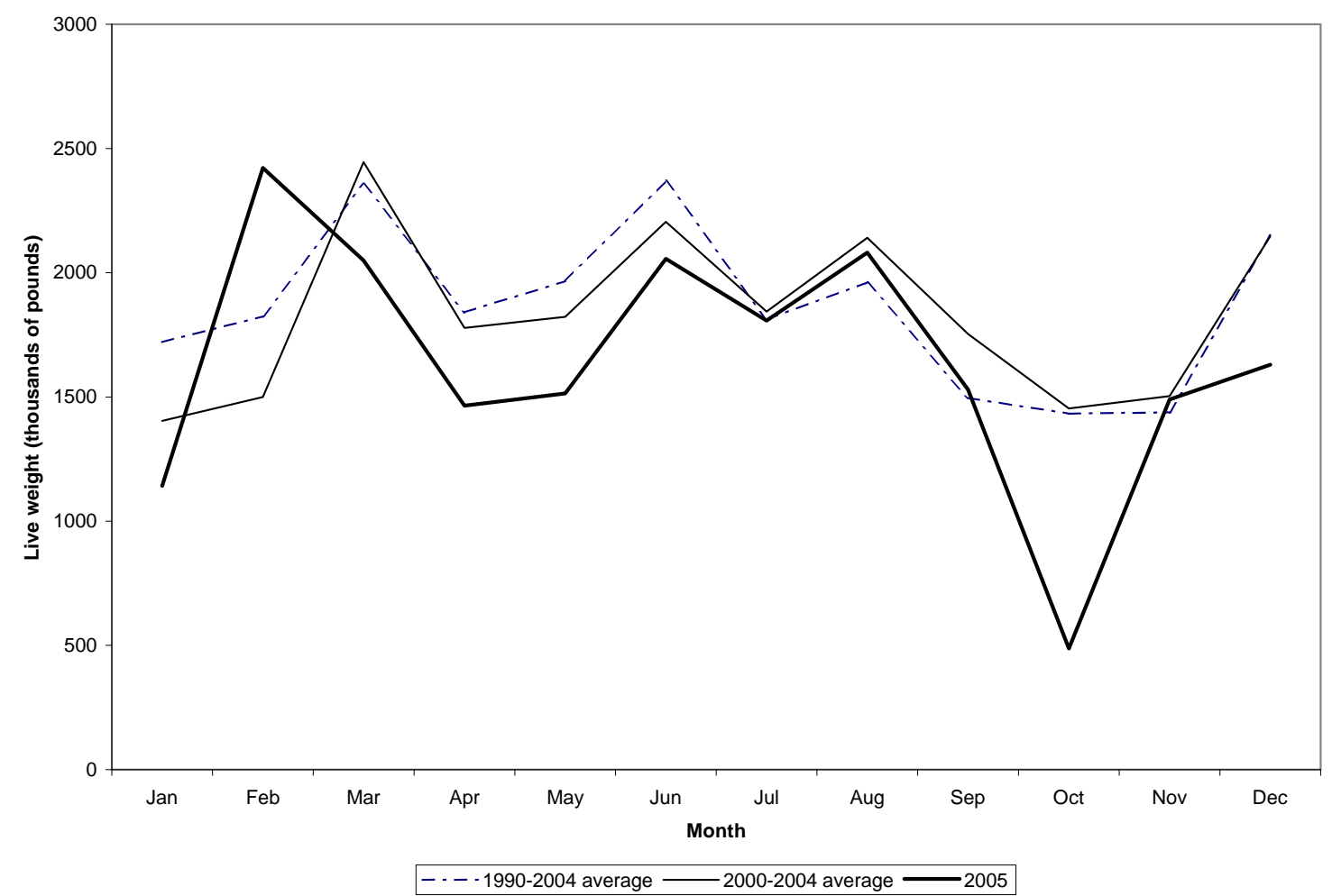

Note: 1990-2004 average excludes 1993 (when red tide also occurred). 
Figure 6. Changes in Annual Shellfish Landings in Massachusetts:

Baseline versus 2005

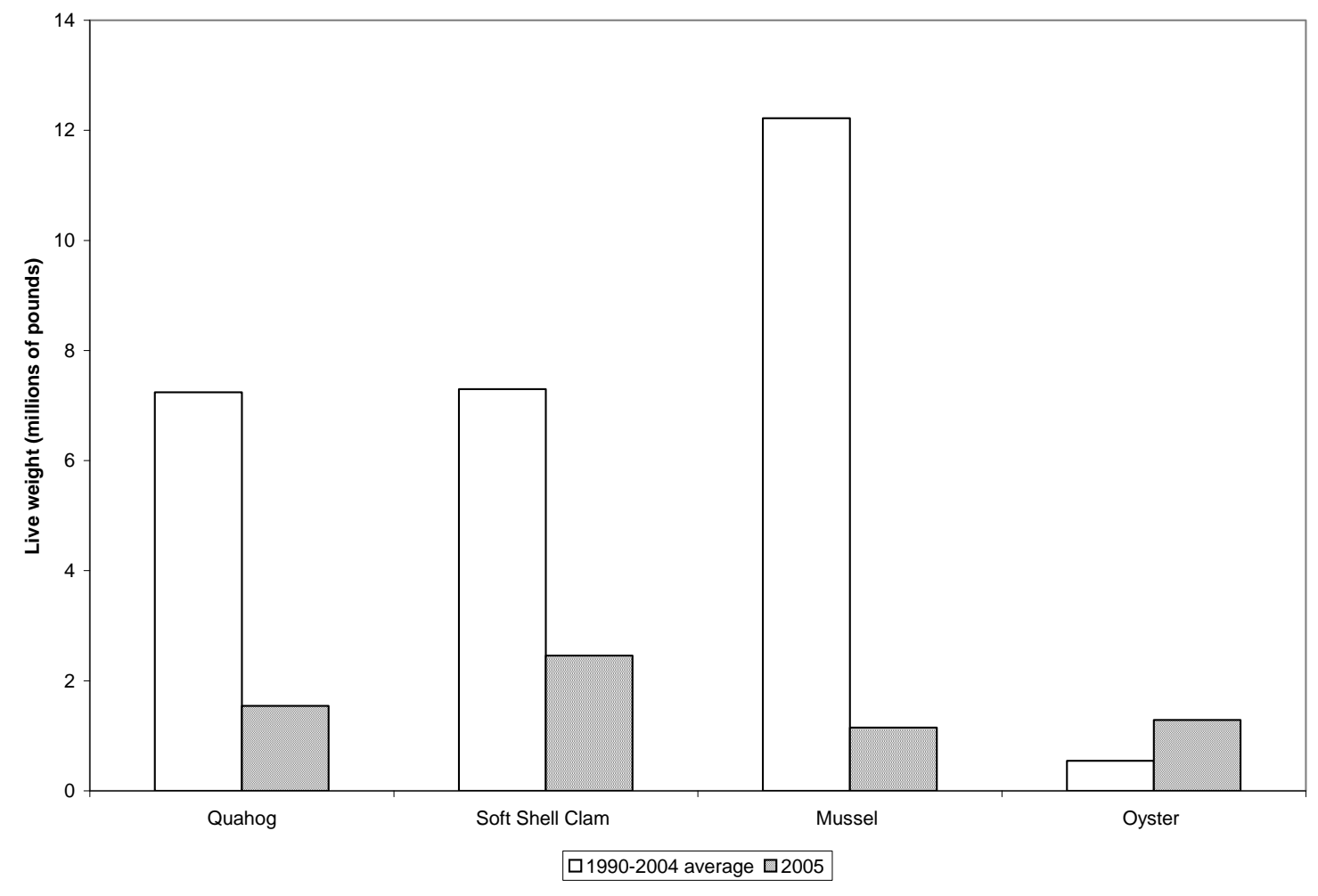

Notes: 1990-2004 average and 2005 data from Table 2. 
Figure 7. Monthly Mussel Landings in Massachusetts: Baseline versus 2005

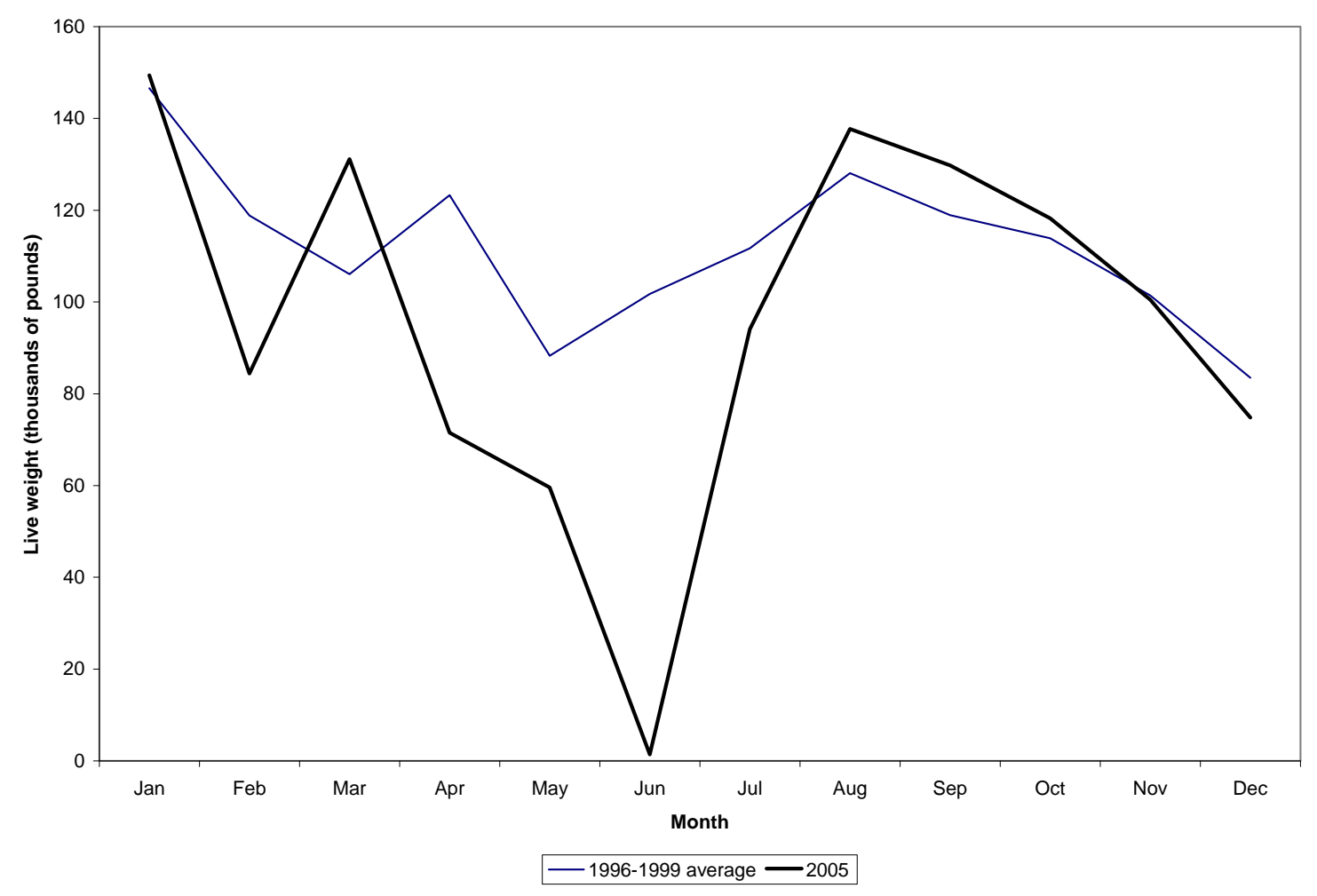

Note: Since complete monthly mussel landing data are not available, the baseline is constructed in two steps. First, average monthly shares are estimates using partial mussel landing data from MNFS. Next, the shares are applied to the 1996-1999 annual average based on data from Massachusetts Division of Marine Fisheries (see Table 2). 2005 data are from NMFS. 
Figure 8. Softshell Clam Wholesale Prices on New York Fulton Fish Market: Baseline versus 2005

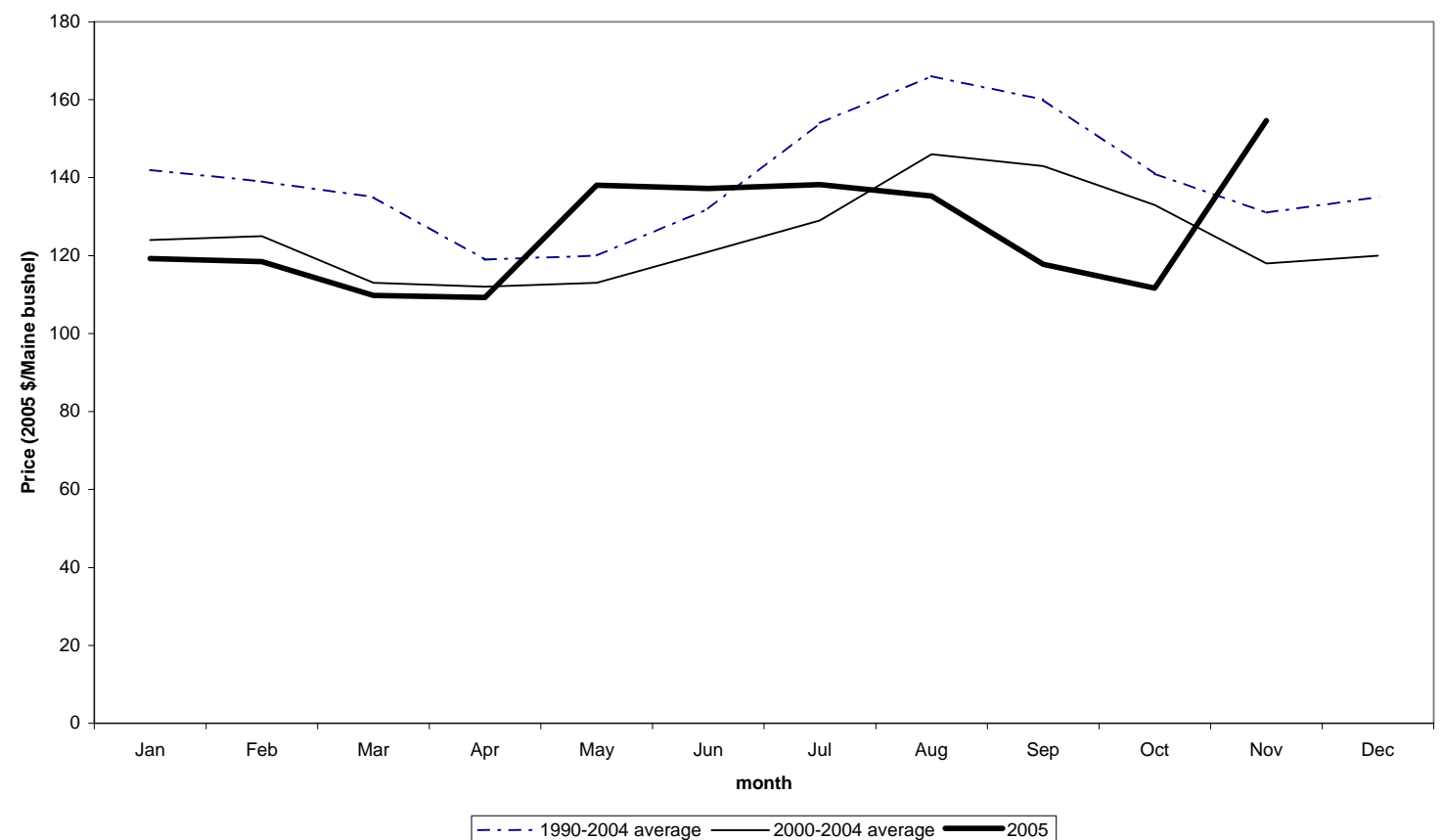

